\title{
Thermal inactivation of spores of Bacillus atrophaeus, Bacillus anthracis, Bacillus cereus, and Clostridium difficile
}

\author{
Shigeharu Oie ${ }^{* 1}$, Tomoko Ohkusa ${ }^{1}$, Akira Kamiya ${ }^{1}$, Akiko Okutani ${ }^{2}$, Satoshi Inoue ${ }^{2}$ \\ ${ }^{1}$ Department of Nursing, Ube Frontier University, Japan \\ ${ }^{2}$ Department of Veterinary Science, National Institute of Infectious Diseases, Japan
}

\author{
Received: May 11, 2017 \\ Accepted: July 30, 2017 \\ Online Published: August 9, 2017 \\ DOI: $10.5430 /$ jha.v6n5p9 \\ URL: https://doi.org/10.5430/jha.v6n5p9
}

\begin{abstract}
There are inadequate evidence on the sporicidal effect of hot water. Therefore, we evaluated the efficacy of hot water against spores of Bacillus atrophaeus, Bacillus anthracis, Bacillus cereus, and Clostridium difficile. A portion ( $0.05 \mathrm{ml})$ of the spore suspension was used to inoculate $4.95 \mathrm{ml}$ of sterilized distilled hot water. After standing for 1, 2, 5, 10, 30, and $60 \mathrm{~min}$, $0.5 \mathrm{ml}$ was added to $4.5 \mathrm{ml}$ of physiological saline at room temperature $\left(20^{\circ} \mathrm{C}-22^{\circ} \mathrm{C}\right)$. The spores of $B$. atrophaeus were the most resistant to hot water, followed by those of B. anthracis, B. cereus, and C. difficile. Disinfection of spores using hot water required contact at $100^{\circ} \mathrm{C}$ for $30 \mathrm{~min}$ for B. atrophaeus and B. anthracis, at $90^{\circ} \mathrm{C}$ for $30 \mathrm{~min}$ or at $100^{\circ} \mathrm{C}$ for $5 \mathrm{~min}$ for B. cereus, and at $90^{\circ} \mathrm{C}$ for $10 \mathrm{~min}$ or at $100^{\circ} \mathrm{C}$ for $2 \mathrm{~min}$ for $C$. difficile. All tested spores cannot be killed under the general conditions of use of hot-water washing machines $\left(70^{\circ} \mathrm{C}-80^{\circ} \mathrm{C}, 10 \mathrm{~min}\right)$, but the spores of $C$. difficile can be killed under the general conditions of use of washer disinfectors $\left(90^{\circ} \mathrm{C}-93^{\circ} \mathrm{C}, 10 \mathrm{~min}\right)$.
\end{abstract}

Key Words: Hot water, Disinfection, Spore, Bacillus anthracis, Bacillus cereus, Clostridium difficile

\section{INTRODUCTION}

In medical institutions in Japan, hot-water disinfection has become widespread, following the example of the Europe. ${ }^{[1,2]}$ Washer disinfectors are used to disinfect metal instruments and hot-water washing machines to disinfect linens. Previous studies showed that these devices when used under conditions such as $80^{\circ} \mathrm{C}-93^{\circ} \mathrm{C}$ for $10 \mathrm{~min}$ and $80^{\circ} \mathrm{C}$ for $10 \mathrm{~min}$, respectively, are effective against not only vegetative bacteria but also viruses. ${ }^{[1-8]}$ However, there are inadequate data on the sporicidal effects of hot water on bacterial spores. ${ }^{[9]}$ Therefore, we evaluated the sporicidal effects of hot water $\left(80^{\circ} \mathrm{C}-100^{\circ} \mathrm{C}\right)$ on Bacillus anthracis as an important bioterrorism-related microorganism, Bacillus cereus as a common contaminant of linens, and Clostridium difficile as an important pathogen causing nosocomial infection. ${ }^{[10-12]}$ The spores of B. atrophaeus is widely used as an indicator of sterilization.

\section{METERIALS AND METHODS}

Four bacterial strains were evaluated: B. atrophaeus ATCC6633, B. anthracis $34 \mathrm{~F}_{2}$ (vaccine strain for horse and cattle, pXO1 positive, pXO2 negative; Kaketsuken, Kumamoto, Japan), B. cereus NIID-3, and C. difficile ATCC9689. For $C$. difficile, 2 clinical isolates (from 2 patients at Yamaguchi University Hospital) were also used. For spore preparation of B. atrophaeus and B. cereus, the

*Correspondence: Shigeharu Oie; Email: oie@ frontier-u.jp; Address: Department of Nursing, Ube Frontier University, Japan. 
previously reported preparation method for the spores of B. atrophaeus was employed. ${ }^{[13]}$ For spore preparation of $B$. anthracis, a bacterial inoculum cultured on nutrient agar was suspended in saline. This suspension was inoculated into nutrient broth and cultured at $37^{\circ} \mathrm{C}$ for $10-17$ days until more than $80 \%$ of bacteria had initiated spore formation. These spores were then resuspended in saline with 50 vol\% glycerol added and heated at $65^{\circ} \mathrm{C}$ for $60 \mathrm{~min}$ to kill vegetative cells. A spore suspension containing $10^{8}$ colony forming units $(\mathrm{cfu}) / \mathrm{ml}$ was obtained. For spore preparation of C. difficile, the previously reported method was employed. ${ }^{[13]}$

A portion $(0.05 \mathrm{ml})$ of the spore suspension was used to inoculate $4.95 \mathrm{ml}$ of sterilized distilled hot water, which had been heated at different temperatures in a thermostat (Isotemp, Fisher Scientific, USA), and vortexed for $5 \mathrm{sec}-$ onds. After standing for 1, 2, 5, 10, 30, and $60 \mathrm{~min}$, $0.5 \mathrm{ml}$ was added to $4.5 \mathrm{ml}$ of physiological saline at room temperature $\left(20^{\circ} \mathrm{C}-22^{\circ} \mathrm{C}\right)$ and vortexed for 10 seconds. The spores of B. atrophaeus, B. anthracis, and B. cereus were counted as previously reported for $B$. atrophaeus. The spores of $C$. difficile were also counted as previously reported for
C. difficile, although the medium was replaced with chrom ID $C$. difficile agar (bioMérieux SA, France). ${ }^{[13]}$ Experiments were performed three times, and the mean value was calculated.

\section{RESUltS}

Table 1 displays the efficacy of hot water $\left(80^{\circ} \mathrm{C}-100^{\circ} \mathrm{C}\right)$ against the spores of the 4 bacterial species. Hot water at $80^{\circ} \mathrm{C}$ did not kill the spores of B. atrophaeus, B. anthracis, or B. cereus even after contact for $60 \mathrm{~min}$, but killed $C$. difficile spores after contact for $60 \mathrm{~min}$. Hot water at $90^{\circ} \mathrm{C}$ did not kill the spores of $B$. atrophaeus or B. anthracis after contact for $60 \mathrm{~min}$, but killed the spores of $B$. cereus after contact for $30 \mathrm{~min}$ and on those of $C$. difficile after contact for $5 \mathrm{~min}$. Hot water at $100^{\circ} \mathrm{C}$ killed the spores of B. atrophaeus and B. anthracis after contact for $30 \mathrm{~min}$, on those of B. cereus after contact of $5 \mathrm{~min}$, and on those of $C$. difficile after contact for $1 \mathrm{~min}$. Table 2 charts the efficacy of hot water against 2 clinical isolates of $C$. difficile. The clinical isolates were slightly more resistant to hot water than those of standard strain.

Table 1. Efficacy of hot water against spores of 4 bacterial species* in suspension test

\begin{tabular}{|c|c|c|c|c|c|c|c|c|}
\hline \multirow{2}{*}{$\begin{array}{l}\text { Hot water } \\
\text { temperature }\end{array}$} & \multirow{2}{*}{ Bacterial species } & \multicolumn{7}{|c|}{ Spore count $(\mathrm{cfu} / \mathrm{mL})$ after contact time (minute) at } \\
\hline & & $\mathbf{0}$ & 1 & 2 & 5 & 10 & 30 & 60 \\
\hline \multirow{4}{*}{$80^{\circ} \mathrm{C}$} & Bacillus atrophaeus & $2.5 \times 10^{6}$ & $9.1 \times 10^{5}$ & $1.7 \times 10^{6}$ & $6.0 \times 10^{5}$ & $1.3 \times 10^{6}$ & $4.6 \times 10^{5}$ & $5.3 \times 10^{5}$ \\
\hline & Bacillus anthracis & $1.1 \times 10^{6}$ & $1.1 \times 10^{6}$ & $9.3 \times 10^{5}$ & $7.8 \times 10^{5}$ & $7.5 \times 10^{5}$ & $5.8 \times 10^{5}$ & $2.6 \times 10^{5}$ \\
\hline & Bacillus cereus & $8.3 \times 10^{4}$ & $8.6 \times 10^{4}$ & $7.8 \times 10^{4}$ & $4.2 \times 10^{4}$ & $5.7 \times 10^{4}$ & $9.7 \times 10^{3}$ & $1.7 \times 10^{2}$ \\
\hline & Clostridium difficile & $4.8 \times 10^{5}$ & $1.7 \times 10^{5}$ & $8.0 \times 10^{4}$ & $2.5 \times 10^{4}$ & $5.3 \times 10^{3}$ & 33.3 & $<5$ \\
\hline \multirow{4}{*}{$90^{\circ} \mathrm{C}$} & Bacillus atrophaeus & $2.0 \times 10^{6}$ & $9.2 \times 10^{5}$ & $1.2 \times 10^{6}$ & $1.3 \times 10^{6}$ & $8.6 \times 10^{5}$ & $1.1 \times 10^{6}$ & $8.6 \times 10^{5}$ \\
\hline & Bacillus anthracis & $1.1 \times 10^{6}$ & $5.2 \times 10^{5}$ & $7.0 \times 10^{5}$ & $3.5 \times 10^{5}$ & $9.5 \times 10^{4}$ & $1.2 \times 10^{3}$ & 50 \\
\hline & Bacillus cereus & $1.1 \times 10^{5}$ & $1.1 \times 10^{5}$ & $5.5 \times 10^{4}$ & $5.8 \times 10^{3}$ & $6.5 \times 10^{2}$ & $<5$ & $<5$ \\
\hline & Clostridium difficile & $4.8 \times 10^{5}$ & $7.3 \times 10^{3}$ & $6.0 \times 10^{2}$ & $<5$ & $<5$ & $<5$ & $<5$ \\
\hline \multirow{4}{*}{$100^{\circ} \mathrm{C}$} & Bacillus atrophaeus & $2.1 \times 10^{6}$ & $8.4 \times 10^{5}$ & $7.7 \times 10^{5}$ & $1.3 \times 10^{6}$ & $8.9 \times 10^{5}$ & $<5$ & $<5$ \\
\hline & Bacillus anthracis & $1.1 \times 10^{6}$ & $4.5 \times 10^{5}$ & $1.2 \times 10^{5}$ & $4.8 \times 10^{2}$ & $1.0 \times 10^{2}$ & $<5$ & $<5$ \\
\hline & Bacillus cereus & $1.1 \times 10^{5}$ & $8.7 \times 10^{2}$ & $1.2 \times 10^{2}$ & $<5$ & $<5$ & $<5$ & $<5$ \\
\hline & Clostridium difficile & $5.0 \times 10^{5}$ & $<5$ & $<5$ & $<5$ & $<5$ & $<5$ & $<5$ \\
\hline
\end{tabular}

Note. ${ }^{*}$ B. atrophaeus ATCC6633, B. anthracis $34 \mathrm{~F}_{2}$, B. cereus NIID-3, C. difficile ATCC9689

Table 2. Efficacy of hot water against spores of 2 clinical isolates of Clostridium difficile in suspension test

\begin{tabular}{|c|c|c|c|c|c|c|c|c|}
\hline \multirow{2}{*}{$\begin{array}{c}\text { Hot water } \\
\text { temperature }\end{array}$} & \multirow{2}{*}{ Strain no. } & \multicolumn{7}{|c|}{ Spore count $(\mathrm{cfu} / \mathrm{mL})$ after contact time (minute) at } \\
\hline & & $\mathbf{0}$ & 1 & 2 & 5 & 10 & 30 & 60 \\
\hline \multirow{2}{*}{$80^{\circ} \mathrm{C}$} & 1 & $5.4 \times 10^{6}$ & $1.8 \times 10^{6}$ & $2.4 \times 10^{6}$ & $7.5 \times 10^{5}$ & $7.3 \times 10^{5}$ & $7.5 \times 10^{4}$ & $4.7 \times 10^{2}$ \\
\hline & 2 & $8.0 \times 10^{6}$ & $5.8 \times 10^{5}$ & $8.0 \times 10^{5}$ & $7.2 \times 10^{5}$ & $2.4 \times 10^{5}$ & $1.3 \times 10^{3}$ & $<5$ \\
\hline \multirow{2}{*}{$90^{\circ} \mathrm{C}$} & 1 & $5.4 \times 10^{6}$ & $1.3 \times 10^{6}$ & $4.6 \times 10^{3}$ & 17 & $<5$ & $<5$ & $<5$ \\
\hline & 2 & $8.0 \times 10^{6}$ & $5.2 \times 10^{4}$ & $4.3 \times 10^{2}$ & $<5$ & $<5$ & $<5$ & $<5$ \\
\hline \multirow{2}{*}{$100^{\circ} \mathrm{C}$} & 1 & $5.4 \times 10^{6}$ & 17 & $<5$ & $<5$ & $<5$ & $<5$ & $<5$ \\
\hline & 2 & $8.0 \times 10^{6}$ & 33 & $<5$ & $<5$ & $<5$ & $<5$ & $<5$ \\
\hline
\end{tabular}




\section{Discussion}

While hot-water disinfection requires careful attention to avoid burns, it has no residual toxicity associated with hazardous exposures. Indeed, disinfection with hot water is safer than that with chemical disinfectants. In addition, the effects of hot-water disinfection are reliable, and its operating cost is low. For such reasons, hot-water disinfection is the first choice for viruses and vegetative bacteria in medical institutions. However, bacterial spores are widely known to be resistant to hot water. Therefore, we evaluated the sporicidal effects of hot water on B. anthracis, B. cereus and C. difficile. B. anthracis is as an important bioterrorism-related microorganism, B. cereus tends to contaminate linens, and C. difficile is a major pathogen of nosocomial infection. We determined whether their spores are killed by hot-water disinfection using washer disinfectors or hot-water washing machines.

Among the 4 bacterial species evaluated in this study, the spores of $B$. atrophaeus showed the highest hot-water resistance, followed in order by $B$. anthracis, B. cereus, and $C$. difficile. Based on our results, the spores of $B$. anthracis and $B$. cereus cannot be killed under $80^{\circ} \mathrm{C}-93^{\circ} \mathrm{C}$ for $10 \mathrm{~min}$, which is a setting commonly used for hot-water disinfection systems (see Table 1). A previous study showed that the spores of $B$. anthracis could be killed with hot water at $100^{\circ} \mathrm{C}$ for $5 \mathrm{~min}$, but they could not be killed under these conditions in the present study, which might have been due to a difference in the bacterial strain. ${ }^{[11]}$ On the other hand, the spores of a total of $3 C$. difficile strains could not be killed after contact with hot water at $80^{\circ} \mathrm{C}$ for $10 \mathrm{~min}$, but they are killed under hot-water conditions such as $90^{\circ} \mathrm{C}-93^{\circ} \mathrm{C}$ for $10 \mathrm{~min}$ (see Tables 1 and 2). Based on these results, methods using washer disinfectors at $90^{\circ} \mathrm{C}-93^{\circ} \mathrm{C}$ for $10 \mathrm{~min}$ can be also recommended for the disinfection of instruments contaminated with the spores of $C$. difficile.

\section{Conclusions}

The spores of Bacillus atrophaeus showed the highest hotwater resistance, followed in order by B. anthracis, B. cereus, and Clostridium difficile. Hot water at $90^{\circ} \mathrm{C}$ killed the spores of $C$. difficile after contact for $10 \mathrm{~min}$.

\section{CONFLicts OF INTEREST Disclosure}

\section{REFERENCES}

[1] Barrie D. How hospital line and laundry services are provided. J Hosp Infect. 1994; 27: 219-235. https ://doi .org/10.1016/01 95-6701 (94) 90130-9

[2] Barrie D. The provision of food and catering services in hospital. J Hosp Infect. 1996; 33: 13-33. https : //doi .org/10.1016/S019 5-6701 (96) 90026-2

[3] Cannon JL, Papafragkou E, Park GW, et al. Surrogates for the study of norovirus stability and inactivation in the environment: a comparison of murine norovirus and feline calicivirus. J Food Protect. 2006; 69: 2761-2765. https://doi.org/10.4315/0362-028X-69.11 .2761

[4] Collins BJ. Heat disinfection and disinfector machines. J Sterile Serv Manage. 1984; 3: 7-8.

[5] Dohmae S, Okubo T, Higuchi W, et al. Bacillus cereus nosocomial infection from reused towels in Japan. J Hosp Infect. 2008; 69: 361367. PMid: 18602188. https://doi.org/10.1016/j.jhin.200 8.04 .014

[6] Ebner W, Eitel A, Scherrer M, et al. Can household dishwashers be used to disinfect medical equipment? J Hosp Infect. 2000; 45: 155-159. PMid: 10860692. https://doi.org/10.1053/jhin.1 999.0720
[7] Gerding DN, Muto CA, Owens RC Jr. Measures to control and prevent Clostridium difficile infection. Clin Infect Dis. 2008; 46: S43-49. PMid: 18177221. https://doi.org/10.1086/521861

[8] Miles RS. What standards should we use for the disinfection of large equipment? J Hosp Infect. 1991; 18: 264-273. https: //doi.org/10.1016/0195-6701(91)90032-4

[9] Nyström B. New technology for sterilization and disinfection. Am J Med. 1991; 91: 264S-266S. https : //doi .org/10.1016/0002 -9343(91) 90379-C

[10] Oie S, Kamiya A, Tomita M, et al. Efficacy of disinfectants and heat against Escherichia coli O157:H7. Microbios. 1999; 98: 7-14. PMid: 10413874.

[11] Whitney EAS, Beatty ME, Taylor TH Jr, et al. Inactivation of Bacillus anthracis spores. Emerg Infect Dis. 2003; 9: 623-627. PMid: 12781999. https://doi.org/10.3201/eid0906.020377

[12] World Health Organization. Anthrax in Humans and Animals Fourth Edition, WHO Global Alert and Response Report. Available from: http://www. who.int/csr/resources/publicat ions/anthrax_webs.pdf

[13] Oie S, Obayashi A, Yamasaki H, et al. Disinfection methods for spores of Bacillus atrophaeus, B. anthracis, Clostridium tetani, C. botulinum and C. difficile. Biol Pharm Bull. 2011; 34: 1325-1329. PMid: 21804226. https ://doi .org/10.1248/bpb. 34.1325 